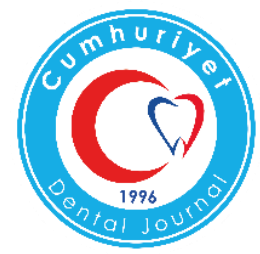

\title{
SHEAR BOND STRENGTH OF TWO CALCIUM SILICATE-BASED CEMENTS TO COMPOMER
}

\author{
Kompomerin Kalsiyum Silikat Esaslı Simanlara Olan Makaslama Bă̆lanma \\ Dayanımı
}

Burak BULDUR, Fatih OZNURHAN, Mevlut KAYABASI, Feride SAHIN

\author{
Makale Kodu/Article Code : 381422 \\ Makale Gönderilme Tarihi $\quad: 19.01 .2018$ \\ Kabul Tarihi $\quad: 08.02 .2018$
}

\section{ABSTRACT}

Objectives: The purposes of this in vitro study was to compare the bond strength of Biodentine ${ }^{\circledR}$ and Imicryl MTA to a compomer material, and to examine the effect of the setting time on the bond strength.

\begin{abstract}
Materials and Methods: A total of 100 acrylic blocks with a hole (4 $\mathrm{mm}$ in diameter and $2 \mathrm{~mm}$ in height) were prepared. Acrylic blocks were randomly divided into two main groups according to cement type to be applied, Biodontine ${ }^{\circledR}$ or Imicryl MTA $(n=50)$. The specimens of each main group were then divided into 5 subgroups, which were randomized relative to different setting times. (12 minutes, 24 hours, 48 hours, 72 hours, and 96 hours $)(n=10)$. The samples were filled completely with Biodentine $\AA$ or Imicrly MTA according to the manufacturer's instructions. Compomer was placed in this transparent tube with the help of a hand plugger and light cured for 40 seconds with the LED device (Elipar ${ }^{\mathrm{TM}}$, 3M ESPE, MN, USA) to polymerize the compomer. The acrylic molds were fixed to a universal test machine and shear bond strength (SBS) test was made under shear force at a cross-speed of $1 \mathrm{~mm} / \mathrm{min}$. Data were analyzed by a two-way ANOVA and Tukey's posthoc test $(\mathrm{p}=0.05)$.
\end{abstract}

Results: While, Biodentine ${ }^{\circledR}$ had significantly higher SBS values than Imicrly MTA at $12 \mathrm{~m}$ setting time $(\mathrm{p}<0.05)$, there was no difference between Biodentine ${ }^{\circledR}$ and Imicrly MTA among other setting periods ( $p>0.05)$. Regardless of cements tested, there were similar SBS values among pairwise comparisons between setting time groups ( $p>0.05$ ).

Conclusions: There were higher SBS values of Biodentine ${ }^{\circledR}$ to compomer than Imicrly MTA in all setting time groups, the only statistical significance existed in 12 min group.

Keywords: Biodentine ${ }^{\circledR}$, bond strength, calcium silicate-based cement, compomer

\section{ÖZ}

Amaç: $\mathrm{Bu}$ in vitro çalışmanın amacı, Biodentine ${ }^{\circledR}$ ve Imicrly MTA'nın bir kompomer materyaline makaslama bağlanma dayanımını karşılaş̧ırmak ve farklı sertleşme sürelerinin bağlanma dayanımına olan etkisini incelemektir.

Gereç ve Yöntem: Ortası delikli (4 mm çapında ve $2 \mathrm{~mm}$ yüksekliğinde) toplam 100 akrilik blok hazırlandı. Akrilik bloklar uygulanacak siman tipine göre rastgele iki ana gruba ayrıld1, Biodentine ${ }^{\circledR}$ veya Imicrly MTA $(n=50)$. Daha sonra, her bir ana grubun numuneleri, farklı sertleşme sürelerine göre rastgele seçilen 5 alt gruba ayrıldı. (12 dakika, 24 saat, 48 saat, 72 saat ve 96 saat) $(n=10)$. Numuneler, üreticinin talimatlarına göre tamamen Biodentine ${ }^{\circledR}$ veya Imicrly MTA ile dolduruldu. Kompomer materyali şeffaf tüp yardımıyla yerleștirildi ve kompomer LED cihazıyla (EliparTM, 3M ESPE, MN, ABD) 40 saniye 1şıkla polimerize edildi. Akrilik kalıplar universal bir test makinesine sabitlendi ve kesme kuvveti $1 \mathrm{~mm} /$ dakika çapraz hızda olacak şekilde makaslama bağlanma dayanım (MBD) testi yapıldı. Veriler iki yönlü ANOVA ve Tukey's post-hoc testi ile analiz edildi $(\mathrm{p}=0.05)$.

Bulgular: Biodentine ${ }^{\circledR}$ 'in $12 \mathrm{dk}$ sertleşme süresinde Imicrly MTA'ya göre MBD değerlerinde anlamlı derecede yüksek iken $(p<0.05)$ diğer ayar dönemleri arasında Biodentine ${ }^{\circledR}$ ile MTA arasinda anlamlı fark yoktu $(p>0.05)$. Test edilen simanlardan bağımsız olarak, sertleşme süreleri grupları arasındaki çift karşılaştırmalarda benzer MBD değerleri vardı ( $>0.05)$. Sonuçlar: Tüm sertleşme zamanı gruplarında, Biodentine®'in kompomere olan bağlanma dayanım değerleri Imicrly MTA'ya göre daha yüksek görülürken, yalnızca istatistiksel anlamlılık 12 dakika sertleşme süresi grubunda mevcuttu.

Anahtar Kelimeler: Biodentine $₫$, bağlanma dayanımı, kalsiyum silikat esaslı siman, kompomer 


\section{INTRODUCTION}

There is an increasing interest in vital pulp treatments in recent years to preserve the vitality of the pulp after dental caries or traumatic dental injuries. ${ }^{1}$ Despite the common use of calcium hydroxide $\left(\mathrm{Ca}(\mathrm{OH})_{2}\right)$ in dental therapies previously ${ }^{2}, \quad \mathrm{Ca}(\mathrm{OH})_{2}$ has disadvantages such as limited adhesion to resin-based restorative materials ${ }^{2}$, easily dissolving $^{3}$, and defects in the dentin bridge. ${ }^{4}$ In recent years, calcium-silicate-based cements have been used instead of $\mathrm{Ca}(\mathrm{OH})_{2}$ due to their superior physical ${ }^{5}$ and chemical properties. ${ }^{6}$

Mineral trioxide aggregate (MTA), a mixture of tricalcium aluminate, dicalcium silicate, tricalcium silicate, tetracalcium alumunoferrite and bismuth oxide ${ }^{7}$, is frequently used in vital pulp treatments due to its favorable biological properties ${ }^{8}$, and positive clinical and histological results. ${ }^{9}$ However, there are disadvantages such as difficulty of manipulation and long setting time. ${ }^{10}$ In recent years, Biodentine ${ }^{\circledR}$ has been developed as an alternative to MTA, which has a wider scope in terms of its use as well as some differences in content. ${ }^{11}$ Biodentine ${ }^{\circledR}$ is recommended to be used under resin-based restorations because of its good physical and chemical properties and the short setting. ${ }^{12}$ Also, Biodentine ${ }^{\circledR}$ does not cause tooth discoloration. $^{13}$

The bond strength of dentine between restorative materials is important for clinical success. ${ }^{14}$ Also, clinical success of compomer, which is commonly used as a restorative material in pediatric dentistry ${ }^{15}$, can be increased by the absence of gaps in margins and the good adhesion with pulp capping. Knowing the effect of calcium-silicate based cements on the bond strength of compomer can increase clinical success. In the literature, studies evaluating the success of adhesion between compomer and calcium silicate-based cements are limited.
The purposes of this in vitro study was to compare the bond strength of Biodentine ${ }^{\circledR}$ and MTA to a compomer material, and to examine the effect of the setting time on the bond strength. The null hypotheses of this study were as follow: (a) There is no difference between the bond strength values of MTA and Biodentine ${ }^{\circledR}$ to compomer; (b) There is no effect of setting time on the bond strength of MTA and Biodentine ${ }^{\circledR}$ to compomer.

\section{MATERIALS AND METHOD}

One commercial compomer and 2 calcium silicate-based cements were used in this study. The contents of the materials used in the study are shown in Table 1. A total of 100 acrylic blocks with a hole $(4 \mathrm{~mm}$ in diameter and 2 $\mathrm{mm}$ in height) were prepared. Acrylic blocks were randomly divided into two main groups according to cement type to be applied, Biodentine or Imicrly MTA $(n=50)$. The specimens of each main group were then divided into 5 subgroups, which were randomized relative to different setting times. (12 minutes, 24 hours, 48 hours, 72 hours, and 96 hours) $(n=10)$.

Table 1. Tested materials and their composition with application steps

\begin{tabular}{|c|c|c|c|}
\hline MATERIALS & $\begin{array}{l}\text { PRODUCING } \\
\text { COMPANY }\end{array}$ & COMPOSITION & APPLICATION STEPS \\
\hline $\begin{array}{l}\text { Tri-calcium } \\
\text { silicate cement }\end{array}$ & $\begin{array}{l}\text { Biodentine® } \\
\text { (Septodont, Saint } \\
\text { Maur des Fosses, } \\
\text { France) }\end{array}$ & $\begin{array}{l}\text { Powder: tri-calcium silicate, di- } \\
\text { calcium silicate, calcium carbonate } \\
\text { and ozide filler, iron oxide, zirconium } \\
\text { oxide } \\
\text { Liquid: calcium chloride, } \\
\text { acceleratorhydrosoluble polymer } \\
\text { water }\end{array}$ & $\begin{array}{l}\text { Mixing the single use } \\
\text { capsules for } 30 \text { seconds } \\
\text { with a high-speed } \\
\text { amalgamator }\end{array}$ \\
\hline $\begin{array}{l}\text { Mineral trioxide } \\
\text { aggregate }\end{array}$ & $\begin{array}{l}\text { MTA (Imicryl, } \\
\text { Konya, TURKY) }\end{array}$ & $\begin{array}{l}\text { Tri-calcium silicate, di-calcium } \\
\text { silicate, bishmut oxidet, tri-calcium } \\
\text { aluminate, calcium sulfate }\end{array}$ & Powder/Liquied: 1:3 \\
\hline Compomer & $\begin{array}{l}\text { Dyract XP, LD } \\
\text { Caulk/Dentsply, } \\
\text { USA }\end{array}$ & $\begin{array}{l}\text { UDMA, carboxylic acid modified } \\
\text { dimethacrylate, TEDGMA, } \\
\text { trimethylcrylate resin BHT, UV } \\
\text { Stabiliser, Strontium-alumino- } \\
\text { sodium- fluorophospor-silicate glass, } \\
\text { iron oxide }\end{array}$ & $\begin{array}{l}\text { Polymerization for } 40 \\
\text { seconds }\end{array}$ \\
\hline
\end{tabular}

\section{Application of cements and compomer}

The samples were filled completely with Biodentine ${ }^{\circledR}$ or Imicrly MTA according to the manufacturer's instructions. During the setting period of each tested group, the cements placed on the molds were covered with moist cotton pellets. Following application of the cements and anticipation of setting times, the compomer material was applied into the center of the cements by a cylindrical transparent tube having a pre-prepared inner ring $(2 \mathrm{~mm}$ in diameter and 
$5 \mathrm{~mm}$ in height). The compomer was placed in this transparent tube with the help of a hand plugger and light cured for 40 seconds with the LED device (Elipar ${ }^{\mathrm{TM}}$, 3M ESPE, MN, USA) to polymerize the compomer. Following the polymerization, the transparent tube around the compomer was precisely cut off in the vertical direction with a bisturis.

\section{Shear Bond Strength Test}

The polymerized specimens were in all groups were incubated for $24 \mathrm{~h}$ under $100 \%$ moisture at $37^{\circ} \mathrm{C}$. SBS test was performed as described previously. ${ }^{16}$ The acrylic molds were fixed to a universal test machine with a right angle to the junction of the knife-edge blade and compomer-cement junction. Measurements were made under shear force at a cross-speed of $1 \mathrm{~mm} / \mathrm{min}$. The test was automatically stopped when the failure was seen and the results were calculated by the computer in newton. The SBS value for each specimen was calculated in megapascals (MPa) by dividing the maximum load at failure $(\mathrm{N})$ by the area of surface adhesion. ${ }^{17}$

\section{Statistical Analysis}

Data were analyzed by SPSS for Windows, Version 22.0 (SPSS Inc., Chicago, IL, USA). The mean and standard deviation values of the SBS were calculated for each group. The effects of the type of endodontic cement and setting time on bond strength were analyzed by a two-way ANOVA and multiple comparisons were performed by Tukey's post-hoc test at the 0.05 significance level.

\section{RESULTS}

The mean and standard deviation values of the SBS for each group are shown in Table 2. While, Biodentine ${ }^{\circledR}$ had significantly higher SBS values than Imicrly MTA at $12 \mathrm{~m}$ setting time $(p<0.05)$, there was no difference between Biodentine ${ }^{\circledR}$ and Imicrly MTA among other setting periods $(p>0.05)$. Regardless of cements tested, there were similar SBS values among pairwise comparisons between setting time groups ( $p>0.05)$.

Table 2. Shear Bond Strength Values (Mean \pm SD) for Each Group (MPa)

\begin{tabular}{ccc}
\hline \multirow{2}{*}{ Setting Time } & \multicolumn{2}{c}{ Calcium Silicate-Based Cement } \\
& MTA & Biodentine \\
\hline $12 \mathrm{~min}$ & $10.78 \pm 2.67^{\mathrm{a}}$ & $18.79 \pm 3.16^{\mathrm{a}}$ \\
$24 \mathrm{~h}$ & $17.30 \pm 2.74$ & $18.38 \pm 2.04$ \\
$48 \mathrm{~h}$ & $17.31 \pm 3.35$ & $18.28 \pm 3.37$ \\
$72 \mathrm{~h}$ & $17.97 \pm 2.76$ & $19.00 \pm 3.07$ \\
$96 \mathrm{~h}$ & $17.75 \pm 2.13$ & $18.67 \pm 3.44$ \\
\hline
\end{tabular}

Shear bond strength values are shown as Mean \pm SD. Same lower-case letter represents statistical significant difference within each row, verified by two-way Anova and Tukey's test $(P>0.05)$.

\section{DISCUSSION}

MTA and Biodentine ${ }^{\circledR}$ have a wide variety of uses in dentistry. ${ }^{7}$ However, due to their high physical properties and excellent biocompatibility, high clinical success has been demonstrated. For this reason, bond strength between calcium silicate cements and restorative materials has a great importance in clinical success. High SBS values show high bonding between the restorative material and cement, which leads to less microleakage. ${ }^{18}$

The most common method for evaluating the adhesive properties of restorative materials is to evaluate the bond strength. ${ }^{19}$ There are several test methods used in the literature for bond strength. ${ }^{14,17}$ The shear bond strength of these methods is the one of the most frequently used in the literature. The SBS test is commonly preferred since the test method and the test samples are easier to prepare with less equipment. ${ }^{20}$ However, there are disadvantages such as non-uniform stress distributions in the bond region. ${ }^{21}$ In our study, the SBS test, one of the frequently used methods in the literature, was used to evaluate the bond strength of Imicrly MTA and Biodentine to compomer.

There is no consensus in the literature about the setting time of calcium silicate-based cements required to achieve optimum physical properties. Although the manufacturers state that 12 minutes for Biodentine and 24 hours for MTA are appropriate setting times. Bodanezi et al. ${ }^{22}$ suggested that at least 72 
hours are required to achieve the desired sealability of the MTA. Differently, Atabek et $a l^{23}$ stated that restorative procedures should be postponed for at least 96 hours after confounding MTA.

This study revealed that while Biodentine ${ }^{\circledR}$ had significantly higher SBS values than Imicrly MTA at $12 \mathrm{~m}$ setting time, there was no difference between Biodentine ${ }^{\circledR}$ and MTA among other setting periods. Unlike this study, Atabek et al. ${ }^{23}$ evaluated the SBS of a composite material to white MTA at different time intervals (4, 24, 48, 72 and 96 hours). They recommend delaying restorative procedures for 96 hours after mixing the MTA to achieve optimal physical properties. The manufacturer announced that the preparation period of Biodentine ${ }^{\circledR}$ was 12 minutes and that the final restoration could be completed in the same session. ${ }^{12}$ In another study, the period of preparation of Biodentine $\AA$ was reported as 45 minutes unlike the time reported by the manufacturer. ${ }^{24}$ Bachoo et al. ${ }^{25}$ reported that after mixing of powder and liquid, Biodentine ${ }^{\circledR}$ received about 12 minutes of initial preparation reaction and 2 weeks to reach the full maturation of Biodentine ${ }^{\circledR}$. The fact that Biodentine ${ }^{\circledR}$ has a shorter preparation period than MTA may be due to the fact that calcium chloride in the liquid portion of Biodentine ${ }^{\circledR}$ accelerates the hydration and penetration of silicates in the powder. In this study, the minimum preparation time was determined to be 12 minutes in accordance with the manufacturer's instructions. In this study, SBS test was applied to the prepared specimens after 12 minutes, 24-48-96 hours after the initial preparation reaction.

SBS values in the group of Biodentine ${ }^{\circledR}$ were found to be statistically significant higher than those of the Imicrly MTA group in the samples that were subjected to the SBS test at the end of the first 12 minutes. This finding is in consistent with the study by Odabas et al. ${ }^{26}$, in which the bond strength of Biodentine ${ }^{\circledR}$ to a resin-based material was tested by dividing it into two time periods of $12 \mathrm{~min}$ and $24 \mathrm{~h}$. In this study, SBS values in the Biodentine ${ }^{\circledR}$ group increased in all setting time groups compared to the Imicrly MTA group after 2448-72-96 hours of setting period, but this increase statistic was not statistically significant. In contrast to this finding, Hashem et $a . .^{27}$ reported that the values of the microshear bond strength test of the Biodentine ${ }^{\circledR}$ groups with longer storage times were higher than those of the groups with shorter storage periods. Biodentine ${ }^{\circledR}$ showed higher SBS values in all groups than the MTA. This may due smaller particular structure of Biodentine ${ }^{\circledR}$ compared to MTA, thus leading a higher adhesion to restorative material.

\section{CONCLUSION}

Within the limitations, it may be concluded that although there were higher SBS values of Biodentine ${ }^{\circledR}$ to compomer than Imicrly MTA in all setting time groups, the only statistical significance existed in 12 min group. For this reason, the use of Biodentine ${ }^{\circledR}$ in pediatric dental practice can be recommended due to its advantages such as short cure time, ease of manipulation and no color change. However, further in vivo studies are necessary to be examine the bond strength of different pediatric restorative materials with different calcium silicate-based cements.

\section{CONFLICTS of INTEREST}

The authors declare no potential conflicts of interest with respect to the authorship and/or publication of this article.

\section{REFERENCES}

1. Martens L, Rajasekharan S, Cauwels R. Pulp management after traumatic injuries with a tricalcium silicate-based cement (Biodentine $^{\mathrm{TM}}$ ): a report of two cases, up to 48 months follow-up. Eur Arch Paediatr Dent 2015;16:491-496.

2. Falster CA, Araujo FB, Straffon LH, Nor J. Indirect pulp treatment: in vivo outcomes of an 
adhesive resin system vs calcium hydroxide for protection of the dentin-pulp complex. Pediatr Dent 2002;24:241-248.

3. Mickenautsch S, Yengopal V, Banerjee A. Pulp response to resin-modified glass ionomer and calcium hydroxide cements in deep cavities: A quantitative systematic review. Dent Mater 2010;26:761-770.

4. Li Z, Cao L, Fan M, Xu Q. Direct pulp capping with calcium hydroxide or mineral trioxide aggregate: a meta-analysis. J Endod 2015;41:1412-1417.

5. Sarkar N, Caicedo R, Ritwik P, Moiseyeva R, Kawashima I. Physicochemical basis of the biologic properties of mineral trioxide aggregate. J Endod 2005;31:97-100.

6. Dawood AE, Parashos P, Wong RH, Reynolds EC, Manton DJ. Calcium silicate-based cements: composition, properties, and clinical applications. J Investig Clin Dent 2017;8:

7. Parirokh M, Torabinejad M. Mineral trioxide aggregate: a comprehensive literature reviewpart I: chemical, physical, and antibacterial properties. J Endod 2010;36:16-27.

8. Cavenago BC, del Carpio-Perochena AE, Ordinola-Zapata R, Estrela C, Garlet GP, Tanomaru-Filho M, Weckwerth PH, de Andrade FB, Duarte MAH. Effect of Using Different Vehicles on the Physicochemical, Antimicrobial, and Biological Properties of White Mineral Trioxide Aggregate. J Endod 2017;43:779-786.

9. Bakhtiar H, Mirzaei H, Bagheri M, Fani N, Mashhadiabbas F, Eslaminejad MB, Sharifi D, Nekoofar M, Dummer P. Histologic tissue response to furcation perforation repair using mineral trioxide aggregate or dental pulp stem cells loaded onto treated dentin matrix or tricalcium phosphate. Clin Oral Investig 2017;1-10.

10.Parirokh M, Torabinejad M. Mineral trioxide aggregate: a comprehensive literature review-part III: clinical applications, drawbacks, and mechanism of action. J Endod 2010;36:400-413.
11.Bronnec F. Biodentine: a dentin substitute for the repair of root perforations, apexification and retrograde root filling. $\mathrm{J}$ Endod 2010;36:400-413.

12.Rajasekharan S, Martens L, Cauwels R, Verbeeck R. Biodentine ${ }^{\mathrm{TM}}$ material characteristics and clinical applications: a review of the literature. Eur Arch Paediatr Dent 2014;15:147-158.

13. Marconyak LJ, Kirkpatrick TC, Roberts HW, Roberts MD, Aparicio A, Himel VT, Sabey KA. A comparison of coronal tooth discoloration elicited by various endodontic reparative materials. J Endod 2016;42:470-473.

14. Alzraikat H, Taha NA, Qasrawi D, Burrow MF. Shear bond strength of a novel light cured calcium silicate based-cement to resin composite using different adhesive systems. Dent Mater J 2016;35:881-887.

15.Blumer S, Peretz B, Ratson T. The Use of Restorative Materials in Primary Molars among Pediatric Dentists in Israel. J Clin Pediatr Dent 2017;41:199-203.

16. Tulumbaci F, Almaz ME, Arikan V, Mutluay MS. Shear bond strength of different restorative materials to mineral trioxide aggregate and Biodentine. J Conserv Dent 2017;20:292.

17.Aydin MN, Buldur B. The effect of intracanal placement of various medicaments on the bond strength of three calcium silicatebased cements to root canal dentin. J Adhes Sci Technol 2018;32:542-552.

18. Retief D, Mandras R, Russell C. Shear bond strength required to prevent microleakage of the dentin/restoration interface. Am J Dent 1994; 7:44-46.

19.Flury S, Peutzfeldt A, Lussi A. Influence of increment thickness on microhardness and dentin bond strength of bulk fill resin composites. Dent Mater 2014;30:1104-1112.

20.Armstrong S, Geraldeli S, Maia R, Raposo LHA, Soares CJ, Yamagawa J. Adhesion to tooth structure: a critical review of "micro" bond strength test methods. Dent Mater 2010;26:e50-e62. 
21.Van Noort R, Noroozi S, Howard I, Cardew G. A critique of bond strength measurements. J dent 1989;17:61-67.

22.Bodanezi A, Carvalho N, Silva D, Bernardineli N, Bramante CM, Garcia RB, Moraes IGd. Immediate and delayed solubility of mineral trioxide aggregate and Portland cement. Journal of Applied Oral Science 2008;16:127-131.

23. Atabek D, Sillelioğlu H, Ölmez A. Bond strength of adhesive systems to mineral trioxide aggregate with different time intervals. J Endod 2012;38:1288-1292.

24. Grech L, Mallia B, Camilleri J. Investigation of the physical properties of tricalcium silicate cement-based root-end filling materials. Dent Mater 2013;29:e20-e28.

25.Bachoo I, Seymour D, Brunton P. A biocompatible and bioactive replacement for dentine: is this a reality? The properties and uses of a novel calcium-based cement. Br Dent J 2013;214:E5-E5.
26. Odabaş ME, Bani M, Tirali RE. Shear bond strengths of different adhesive systems to biodentine. ScientificWorldJournal 2013;2013: 27. Hashem DF, Foxton R, Manoharan A, Watson TF, Banerjee A. The physical characteristics of resin composite-calcium silicate interface as part of a layered/laminate adhesive restoration. Dent Mater 2014;30:343349.

\section{Corresponding Author}

Burak BULDUR

Department of Pediatric Dentistry

Faculty of Dentistry

Cumhuriyet University

Kampus, 58140, Sivas, Turkey

E-mail: bbuldur@gmail.com

bbuldur@cumhuriyet.edu.tr

Phone: +90 346 2191010/ 2757 - 2737 